\title{
High-performance liquid chromatography for determination of $\alpha$-tocopherol in vegetables
}

\author{
MARCIN HORBOWICZ
}

Research Institute of Vegetable Crops, Department of Processing and Freezing, Konstytucji 3 Maja 1/3, 96-100 Skierniewice, Poland

(Received: May 6, 1988)

\begin{abstract}
A simple method for the determination of $\alpha$-tocopherol in vegetables is described. The procedure consists of the following steps: saponification, extraction, silica-column clean-up, and high-performance liquid chromatography. Elution time for D, L- $\alpha$-tocopherol was $9.0 \mathrm{~min}$ using a Zorbax Sil $(250 \times 4.6 \mathrm{~mm})$ column and an isocratic mobile phase of hexane-methanol $(99.3+0.7)$, with a flow rate of $1 \mathrm{ml} / \mathrm{min}$, and detection at $292 \mathrm{~nm}$ using a variable UV detector. The average recovery of $\alpha$-tocopherol was $91.2 \%$, and the minimum detectable amount was $0.1 \mathrm{mg} / 100 \mathrm{~g}$ of fresh vegetable tissue. This method is comparable to gas-chromatographic determination of $\alpha$-tocopherol, but has fewer analytical steps and gives more reproducible results.
\end{abstract}

\section{INTRODUCTION}

Tocopherols are widely distributed in nature. The main sources of tocopherols are plants and plant oils, which contain eight isomers having different vitamin $\mathrm{E}$ activity. The most common and physiologically most active form is $\alpha$-tocopherol. The other isomers are less active, for example, $\beta$-tocopherol contains about one-third $\alpha$-form activity, $\gamma$-tocopherol one-fifth, and $\delta$-tocopherol - one-hundredth (Edisbury et al., 1954).

It is therefore important to have an accurate and precise analytical method which can measure the total amount of this form in plant material.

Many discrepancies exists in literature regarding the $\alpha$-tocopherol content of various vegetables (Christie et al., 1973; Bunnel et al., 1965; Lempka and Kasperek, 1977; Janiček et al., 1977). The differences apparently depend on the various extraction, separation, and detection techniques. The classical method for determination of $\alpha$-tocopherol in vegetables involved extraction, then saponification, followed by separation using TLC or paper chromatography methods, and quantitation using the Emmerie-Engel reaction (Bunnel et al., 1965; Kanner et al., 1979). This method is non-specific, requires long sample preparation and analysis time, and therefore is inaccurate. 
A gas-liquid chromatography method has also been developed for the determination of $\alpha$-tocopherol in vegetables ( $\mathrm{Ch}$ ristie et al., 1973; $\mathrm{Nair}$ and Turner, 1963). $\alpha$-Tocopherol is converted to its trimethylsilyl ether (TMS) derivative, and then analysed by using a column filled with silicone-gum-coated supports.

This time-consuming and expensive preparation can be ommited when high-performance liquid chromatography is used. Recently, various HPLC methods for determing $\alpha$-tocopherol in animal feed and human food have been reported (M c M urra y et al., 1979, 1980; Söderhjelm and Anders on, 1978; Cohen and Lapointe, 1980; Hedlund, 1982).

The purpose of this work was to develop a simple method for the determination of $\alpha$-tocopherol in vegetables and vegetable products. The method described here consists of four main steps: saponification, extraction, silica gel clean-up, and HPLC chromatography.

\section{MATERIALS AND METHODS}

A. Fresh vegetable samples: parsley roots and leaves, canned pepper were bought on the local market, frozen vegetables: leek, green peas, white cabbage and onion leaves were obtained from experiments on the effect of storing frozen vegetables on nutritional quality.

\section{B. Reagents}

Acetone, 96\% ethanol, potassium hydroxide pellets, sodium chloride, anhydrous sodium sulphate - pure for analysis (POCh, Poland);

n-Hexane (Reakhim, USSR) was distilled in glass;

Methanol - Lichrosolv (Merck, FRG), and Silica Woelm TSC, III activity (Woelm Pharma, FRG);

D,L- $\alpha$-tocopherol (Windsor Lab. Ltd., Great Britain) and sililating mixture BA-11, containing BSTFA and $\mathrm{CH}_{3} \mathrm{CN}, 1: 1$ (Chemipan, Poland).

C. Equipment

The liquid chromatography system included: LKB 2150 pump, Rheodyne septumless injector, variable LKB 2151 detector set at $292 \mathrm{~nm}, \mathrm{TZ} 4100$ Line recorder (Lab. Pristroje, Praha), and $250 \times 4.6 \mathrm{~mm}$ stainless steel column containing Zorbax Sil, 5-6 $\mu$ (Du Pont, USA). The flow rate of the mobile phase (n-hexane - methanol, $99.3+0.7$ ) was $1.0 \mathrm{ml} / \mathrm{min}$.

Gas chromatography conditions: a Pye Unicam 204 chromatograph equipped with FID detector maintained at $300^{\circ} \mathrm{C}$, injector, maintained at $300^{\circ} \mathrm{C}$, and column at $270^{\circ} \mathrm{C}$.

A glass column $(250 \times 0.4 \mathrm{~cm})$ was filled with $3 \% \mathrm{SE}-30$ on Gas Chrom $\mathrm{Q}$, 80-100 mesh. Gas flows: carrier (Argon), hydrogen and air were $25 \mathrm{ml} / \mathrm{min}$, $30 \mathrm{ml} / \mathrm{min}, 300 \mathrm{ml} / \mathrm{min}$, respectively. A Waring Blender (100 $\mathrm{ml}$ volume) was 
used to homogenization the samples, the solvents were evaporated in a rotary evaporator (Unipan, Poland), and $25 \times 1 \mathrm{~cm}$ glass columns were used for clean-up.

D. Methods

Saponification

A sample of $5 \mathrm{~g}$ chopped vegetable tissue was homogenized with $30 \mathrm{ml}$ of ethanol for 1 minute. The slurry was transferred to a round bottomed $100 \mathrm{ml}$ flask with $20 \mathrm{ml}$ of ethanol. The mixture was allowed to boil for 5 minutes under a reflux condenser, and then $2 \mathrm{~g}$ of $\mathrm{KOH}$ pellets were added through the condenser. The refluxing was continued for $20 \mathrm{~min}$, after which $25 \mathrm{ml}$ of aqueous $10 \%$ sodium chloride solution were added and the mixture was cooled in cold water.

\section{Extraction}

The cold mixture was extracted with three $50 \mathrm{ml}$ portions of hexane. The combined hexane layers were washed with $50 \mathrm{ml}$ of $10 \%$ sodium chloride solution, next with $50 \mathrm{ml}$ of water. The hexane layer was then dried with $10 \mathrm{~g}$ anhydrous sodium sulphate. The hexane was evaporated to about $10 \mathrm{ml}$ at $40^{\circ} \mathrm{C}$ using a rotary evaporator.

Clean-up

A column was prepared using a slurry of $2 \mathrm{~g}$ silica gel in hexane, and a layer of $1 \mathrm{~cm}$ anhydrous sodium sulphate was placed on top of the silica gel. The hexane solution was applied to the column, washed with $50 \mathrm{ml}$ of hexane, and the hexane eluate was discarded. $\alpha$-Tocopherol was then eluted with $25 \mathrm{ml}$ of hexane-acetone solution $(4: 1)$. The eluate was evaporated to dryness and the residue was immediately and quantitatively transferred to a $10 \mathrm{ml}$ volumetric flask, and used for HPLC measurements.

This procedure was used to test the $\alpha$-tocopherol content in several vegetable species. Before the determinations were conducted, preliminary tests were done to determine the effect of the lenght of the saponification process $(5$, $10,20$ and $30 \mathrm{~min})$ and the potassium hydroxide concentration $(2,4$ and $10 \%$ $\mathrm{w} / \mathrm{v})$ in the saponification mixture on the test results. These studies were done using frozen leek leaves. Recovery of the $\alpha$-tocopherol was estimated by spiking four green pea samples at the rate of $1 \mathrm{mg} / 100 \mathrm{~g}$ added before homogenization and taking each sample through the entire procedure.

After clean-up, and before determination of $\alpha$-tocopherol by the gas chromatography method, a $1 \mathrm{ml}$ hexane aliquot was evaporated to dryness in a stream of argon, and then was silylated with $0.5 \mathrm{ml} \mathrm{BA}-11$ mixture. Standards of tocopherol were prepared in the same way.

Results of determination were calculated based on the calibration curves plotted in the range of 20-400 $\mathrm{ng}$ of tocopherol injected into the liquid chromatograph, and 50-1000 ng injected after silylation into the gas chromatograph. 


\section{RESULTS AND DISCUSSION}

The saponification of whole homogenized materials before the hexane extraction was chosen because Mc Murray et al. (1980) found that direct solvent extraction is inefficient for plant tissues, and can give lower, erroneous results.

The separation of $\alpha$-tocopherol in various solvent systems (hexane-diethyl ether, hexane-n-propyl alcohol, hexane-methanol) was investigated. Satisfactory separations were achieved using a Zorbax Sil column and hexane containing $0.7 \%$ methanol. The same solvent system was used by Vatassery et al. (1978).

The retention time of $\mathrm{D}, \mathrm{L}-\alpha$-tocopherol under our conditions was $9.0 \mathrm{~min}$. The calibration curve was linear within the range of 20-400 ng of tocopherol injected into the liquid chromatograph. The peaks were sharp and symmetrical, therefore the peak height was used to plot the standard curve and to calculate determination results.

Figure 1 shows the chromatograms of $\alpha$-tocopherol standard (A), green peas (B), green peas fortified with $\alpha$-tocopherol (C) and parsley roots (D). The tocopherol peak was clearly separated from any interfering peaks. The minimum concentration of $\alpha$-tocopherol which was determined by the present procedure was $0.1 \mathrm{mg} / 100 \mathrm{~g}$ of fresh weight.

The efficiency of the extraction procedure was tested during the analysis of leek leaves by changing the saponification time, and the concentration of potassium hydroxide. Table 1 shows that too high concentrations of $\mathrm{KOH}$ caused partial decomposition of $\alpha$-tocopherol. Twenty minutes is enough for the full extraction of tocopherol from vegetable tissues.

Because of the instability of tocopherols to oxidizing agents in hot alkaline solutions, extreme care must be taken in the saponification step (Methods of Vitamin Assay, 1966). In the method described above, a blanket of ethanol vapour was used to isolate the saponification mixture from oxygen. Potassium hydroxide pellets were added to minimize the danger of adding dissolved oxygen.

The recovery of $\alpha$-tocopherol after sample preparation and HPLC determination was between 86 and $94 \%$ with a mean $91.2 \%$. Preliminary studies showed that $\alpha$-tocopherol can be effectively extracted from an ethanol $-10 \%$ sodium chloride (2:1) mixture.

The addition of ascorbic acid $(100 \mathrm{mg})$ as an anti-oxidant had no effect on the assay results. Vitamin $\mathrm{C}$ was therefore ommitted since its degradation products formed several compounds gives additional peaks on the chromatogram.

Before the clean-up, the elution pattern on a silica gel column was studied. The recovery of added amounts of tocopherol (20-1000 $\mu \mathrm{g})$ was completed by elution with $25 \mathrm{ml}$ of hexane-acetone (4:1) solution. 

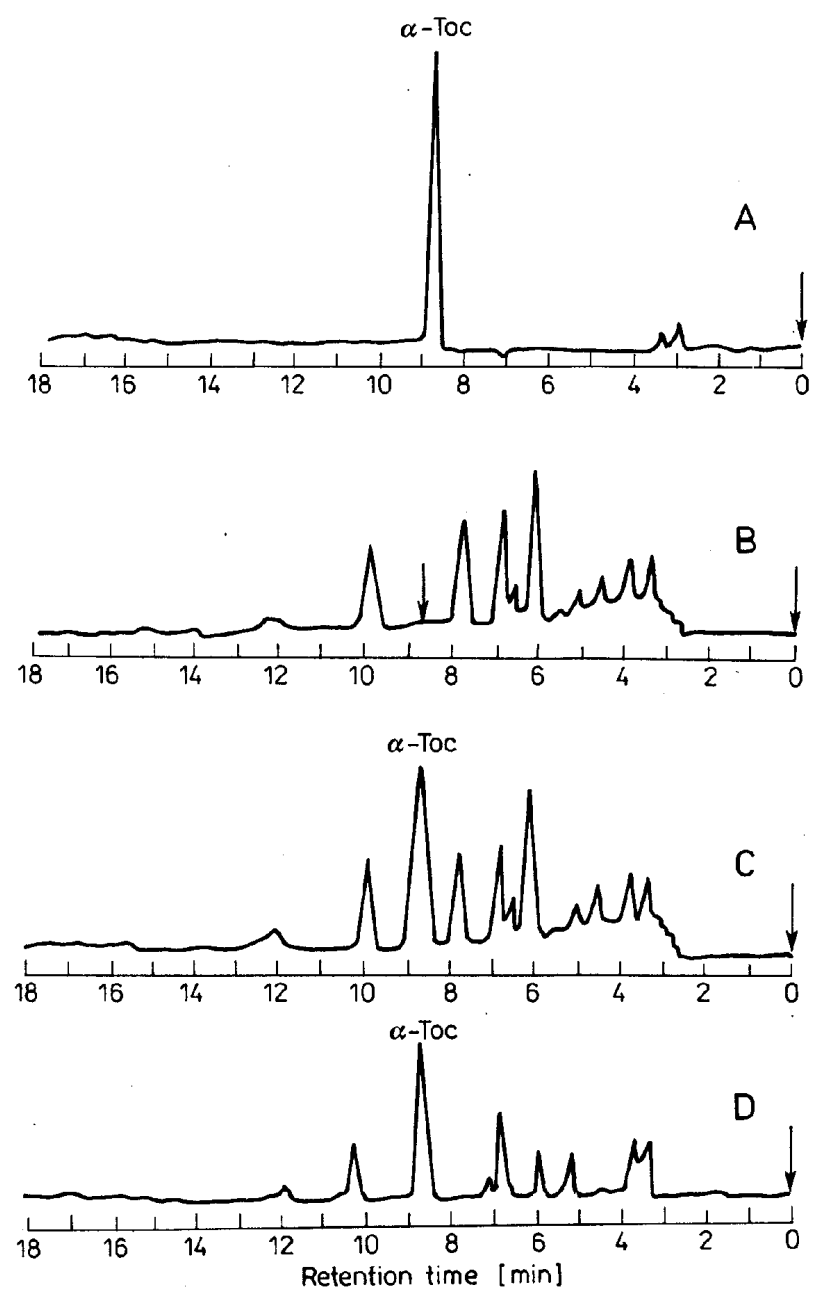

Fig. 1. High-performance liquid chromatograms of $\alpha$-tocopherol standard (A), peas extract (B), peas fortified with $\alpha$-tocopherol (C), and parsley leaves (D)

There were no significant differences between the results obtained by gas chromatography and the HPLC methods (Table 2). Gas chromatography is more time consuming because hexane extracts have to be evaporated to dryness under a stream of inert gas, and the tocopherol has to be converted to a TMS ether. The ether prevents decomposition and tailing of $\alpha$-tocopherol on the gas chromatography column (Christie et al., 1973). Additional steps during the analysis affected the reproducibility of resultes, as shown in Table 2.

Figure 2 shows gas chromatograms of TMS derivatives: D,L- $\alpha$-tocopherol (A) standard, extract of parsley leaves (B) and parsley roots (C). 
Table 1

The effects of saponification time and potassium hydroxide concentration on $\alpha$-tocopherol determination in leek (means of two replicates)

\begin{tabular}{ccc}
\hline $\begin{array}{c}\text { Saponification } \\
\text { time } \\
\text { (minutes) }\end{array}$ & $\begin{array}{c}\text { Concentration } \\
\text { of KOH } \\
(\% \mathrm{w} / \mathrm{v})\end{array}$ & $\begin{array}{c}\alpha \text {-tocopherol } \\
\text { content } \\
(\mathrm{mg} / 100 \mathrm{~g})\end{array}$ \\
\hline 5 & 4 & 2.20 \\
10 & 4 & 2.95 \\
20 & 4 & 3.49 \\
30 & 4 & 3.46 \\
20 & 2 & 3.46 \\
20 & 10 & 3.10 \\
\hline
\end{tabular}

Table 2

Results of $x$-tocopherol determination in parsley and canned pepper by using HPLC and GLC methods (means of three replicates)

\begin{tabular}{lccrcc}
\hline & \multicolumn{2}{c}{ HPLC } & \multicolumn{2}{c}{ GLC } \\
\cline { 2 - 3 } \multicolumn{1}{c}{ Vegetable } & $\begin{array}{c}\text { mean } \\
(\mathrm{mg} / 100 \mathrm{~g})\end{array}$ & $\begin{array}{c}\text { coefficient of } \\
\text { variation }(\%)\end{array}$ & $\begin{array}{r}\text { mean } \\
(\mathrm{mg} / 100 \mathrm{~g})\end{array}$ & $\begin{array}{c}\text { coefficient of } \\
\text { variation }(\%)\end{array}$ \\
\hline Parsley, leaves & 13.94 & 4.7 & 13.70 & 9.5 \\
Parsley, roots & 5.46 & 0.4 & 5.10 & 7.3 \\
Canned pepper & 5.33 & 2.8 & 5.28 & 17.4 \\
\hline \multicolumn{1}{c}{ Mean } & - & 2.6 & - & 11.4 \\
\hline
\end{tabular}

The results of $\alpha$-tocopherol determination in various vegetables are given in Table 3. There is not much information about the $\alpha$-tocopherol content in vegetables as measured using modern techniques, such as HPLC and GLC. On the other hand, the old data are often completly different from those obtained in these studies (Bunnel et al., 1965; Lempka and Kasperek, 1977; Janiček et al., 1977).

$\mathrm{Kanner}$ et al. (1979) found that fresh pepper fruit is one of the richest sources of natural vitamin $\mathrm{E}$ among all vegetables, because it contains from 1.04 to $10.84 \mathrm{mg}$ of vitamin $\mathrm{E}$ in $100 \mathrm{~g}$ of fresh tissue, depending on the maturity and variety of the fruits. During the present studies, canned peppers contained $5.33 \mathrm{mg}$ of $\alpha$-tocopherol $/ 100 \mathrm{~g}$. These results are comparable to the range of vitamin $\mathrm{E}$ published by Kanner et al. (1979).

The author of the present paper found that one of the richest sources of 

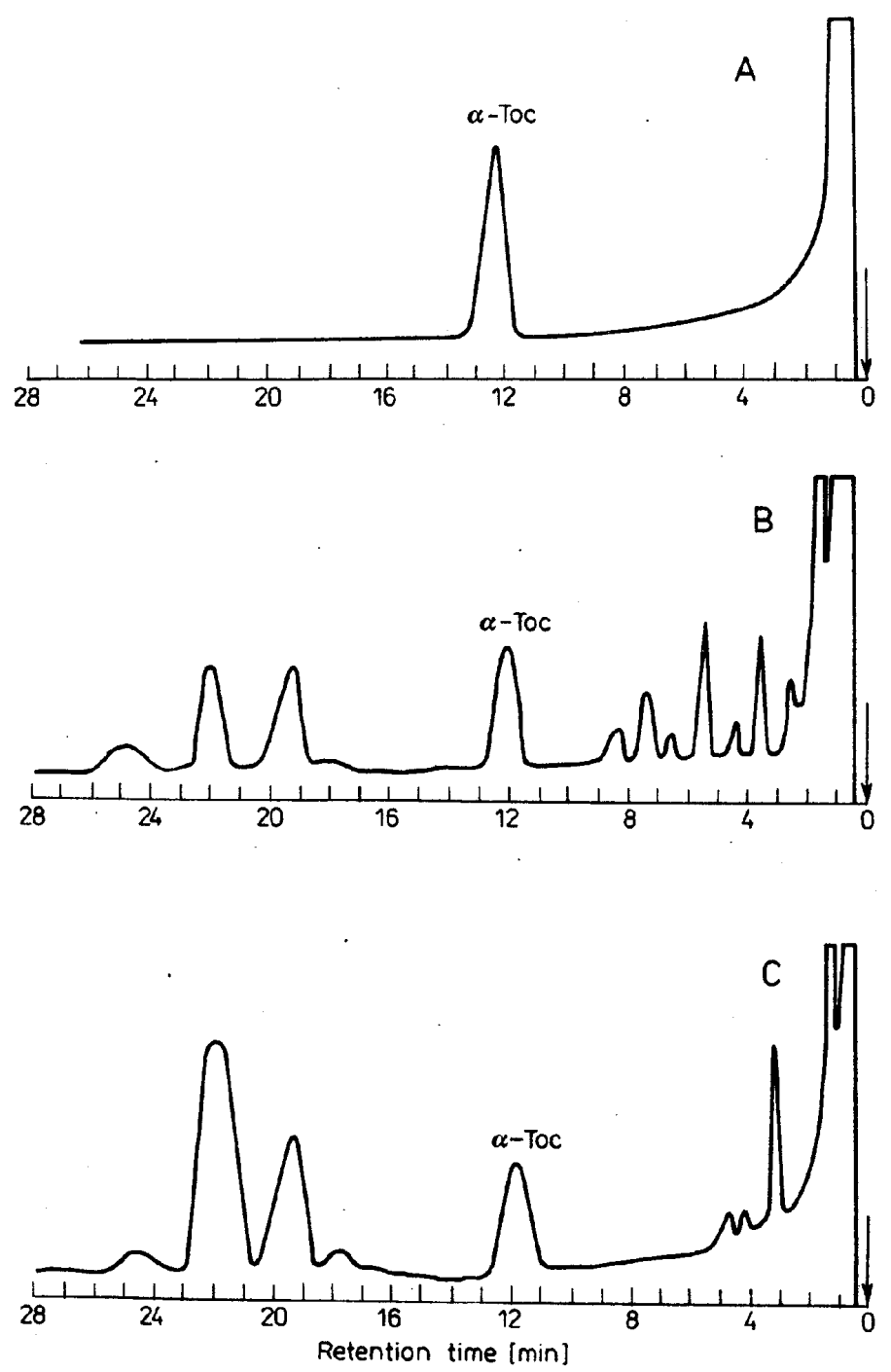

Fig. 2. Gas chromatograms of TMS-derivatives of $\alpha$-tocopherol standard (A), extract of parsley leaves (B), and parsley roots (C)

vitamin $\mathrm{E}$ among the vegetables is parsley leaves, which contained $13.94 \mathrm{mg}$ of $\alpha$-tocopherol/100 $\mathrm{g}$ of fresh tissue. There are no data pertaining to this in the available literature.

Results of $\alpha$-tocopherol tests in lettuce (Table 3) are similar to those obtained by Bunnel et al. (1965), but much lower than data published in some handbooks (Lempka and Kasperek, 1977; Janiček et al., 1977).

From the other results presented in Table 3, it is interesting to note the data 
Table 3

The $\alpha$-tocopherol content in different vegetables (means of three replicates)

\begin{tabular}{lcc}
\hline \multicolumn{1}{c}{$\begin{array}{c}\text { Vegetable, } \\
\text { analysed part }\end{array}$} & $\begin{array}{c}\alpha \text {-tocopherol } \\
\text { content } \\
\text { (mg/100 g) }\end{array}$ & $\begin{array}{c}\text { Coefficient } \\
\text { of. } \\
\text { variation (\%) }\end{array}$ \\
\hline Leek, green leaves* & 3.49 & 4.4 \\
Leek, white leaves* & 0.82 & 7.4 \\
Green peas* & $<0.10$ & - \\
Onion, leaves* & 0.87 & 6.9 \\
White cabbage* & 0.11 & 9.1 \\
Parsley, roots** & 5.46 & 0.4 \\
Parsley, leaves** & 13.94 & 4.7 \\
Watercress** & 4.11 & 2.0 \\
Pepper, canned & 5.33 & 2.8 \\
\hline
\end{tabular}

* Vegetables frozen and stored at $-20^{\circ} \mathrm{c}$ during 3-6 months.

** Fresh vegetables.

on the tocopherol content in leek and watercress. The green part (leaves) of leek contained 4 times more of this vitamin then the white part. A relatively large amount of $\alpha$-tocopherol was detected in 2-week-old watercress. The watercress was prepared by germinating seeds on wet lignin.

\section{CONCLUSION}

1. The described method for $\alpha$-tocopherol determination in vegetables is short, simple and gives accurate results.

2. A 20 -minute saponification time and $4 \%(\mathrm{w} / \mathrm{v})$ of potassium hydroxide concentration during this step is enough to obtain reproducible results.

3. Both gas chromatography and high-performance liquid chromatography methods for determining $\alpha$-tocopherol are comparable, but GC method is more time consuming and gives less reproducible results.

4. The $\alpha$-tocopherol content in vegetables depends on the species and part analysed. High quantities of the vitamin were found in parsley leaves and roots, canned pepper, watercress and leek leaves. Vegetable such as frozen green peas, lettuce and white cabbage contain small quantities of $\alpha$-tocopherol.

\section{REFERENCES}

Bunnel R. H., Keating J., Quaresimo A., Parman G. K., 1965. Alpha-tocopherol content of foods. Am. J. Clin. Nutr. 17: 1-10.

Christie A. A., Dean A. C., Millburn B. A., 1973. The determination of vitamin E in food by colorimetry and gas-liquid chromatography. Analyst 98: 161-167. 
Cohen H., Lapointe M. R., 1980. Determination of vitamin E in animal feeds by normal phase high-performance liquid chromatography. J. A.O.A.C. 63: 1254-1257.

Edisbury J. R., Gillow J., Taylor R. J., 1954. The determination of total tocopherol. Analyst 79: $617-623$

Hedlund B., 1982. Analysis of vitamins in food by HPLC. Proc. 1-st Europ. Conf. Food Chem. Vienna, 27-32.

Janiček G., Pokorny J., Davidek J., 1977. Chemia żywności. WNT, Warszawa, 81-84.

Kanner J., Harel S., Mendel H., 1979. Content and stability of $\alpha$-tocopherol in fresh and dehydrated pepper fruits (Capsicum annum). J. Agr. Food Chem. 27: 1316-1318.

Lempka A., Kasperek M., 1977. Związki chemiczne produktów spoźywczych. PWN, Warszawa-Poznań, 164-166.

Mc Murray C. H., Blanchflower W. J., 1979. Determination of $\alpha$-tocopherol in animal foodstuffs using high-performance liquid chromatography. J. Chromatography 176: 488-492.

Mc Murray C. H., Blanchflower W. J., Rice D. A., 1980. Influence of extraction techniques on determination of $\alpha$-tocopherol in animal feedstuffs. J. A.O.A.C. 63: 1258-1261.

Methods of vitamin assay. 1966. Ass. Vitam. Chemists (Edt). Vitamin E. 363-402.

Nair P. P., Turner D. A., 1963. The application of gas-liquid chromatography to the determination of vitamin E and K. J. Am. Oil Chem. Soc. 40: 353-356.

Söderhjelm P., Andersson B., 1978. Simultaneous determination of vitamin A and E in feeds and foods by reversed phase high-pressure liquid chromatography. J. Sci. Food Agric. 29: 697-702.

Vatassery G. T., Maynard V. R., Hagen D. F., 1978. High-performance liquid chromatography of various tocopherols. J. Chromatography 161: 299-302.

\section{Zastosowanie wysokosprawnej chromatografii cieczowej do oznaczania $\alpha$-tokoferolu w warzywach}

\section{Streszczenie}

Opisano prostą metodę oznaczania $\alpha$-tokoferolu w warzywach. Procedura zawiera cztery etapy: zmydlanie, ekstrakcję, oczyszczanie na kolumnie i pomiary zawartości przy użyciu chromatografu cieczowego. Czas retencji D,L- $x$-tokoferolu wynosil $9.0 \mathrm{~min}$, przy zastosowaniu kolumny Zorbax Sil o wymiarach $250 \times 4,6 \mathrm{~mm}$ oraz fazy ruchomcj heksan-mctanol $(99,3+0,7)$ o przepływie $1,0 \mathrm{ml} / \mathrm{min}$. Zastosowano detektor UV o zmiennej długości fali ustawiony na $292 \mathrm{~nm}$. Średni odzysk $\alpha$-tokoferolu wyniósł $91,2 \%$, a minimalna jego zawartość możliwa do oznaczenia $0,1 \mathrm{mg} / 100 \mathrm{~g}$ świeżej masy.

Metoda jest porównywalna do oznaczania przy pomocy chromatografii gazowej, lecz charakteryzuje się mniejszą liczbą etapów i lepszą powtarzalnością wyników. 